\title{
Citas de autores nacionales en la Revista Médica de Chile
}

\section{References from local authors in Revista Medica de Chile}

$\mathrm{S}_{\mathrm{a}}^{\mathrm{ei}}$ ñor Editor: La revisión de los trabajos publicados en las revistas biomédicas chilenas muestra, en forma generalizada, una escasa mención de referencias bibliográficas de autores chilenos. En otras palabras, se ignora sistemáticamente el trabajo científico médico nacional.

El cuadro adjunto es una muestra tomada de la Revista Médica de Chile (números 10, 11 y 12 del año 2003). Las referencias corresponden a las palabras claves ( Key words») anotadas en los artículos revisados $(*)$.

\section{Dr Alfredo Rioseco Bezanilla}

Coordinador Indice Bibliográfico Médico Chileno 1984-2003. Dirección de Sanidad de la Armada, Viña del Mar. E.mail: alriosbe@hotmail.com.

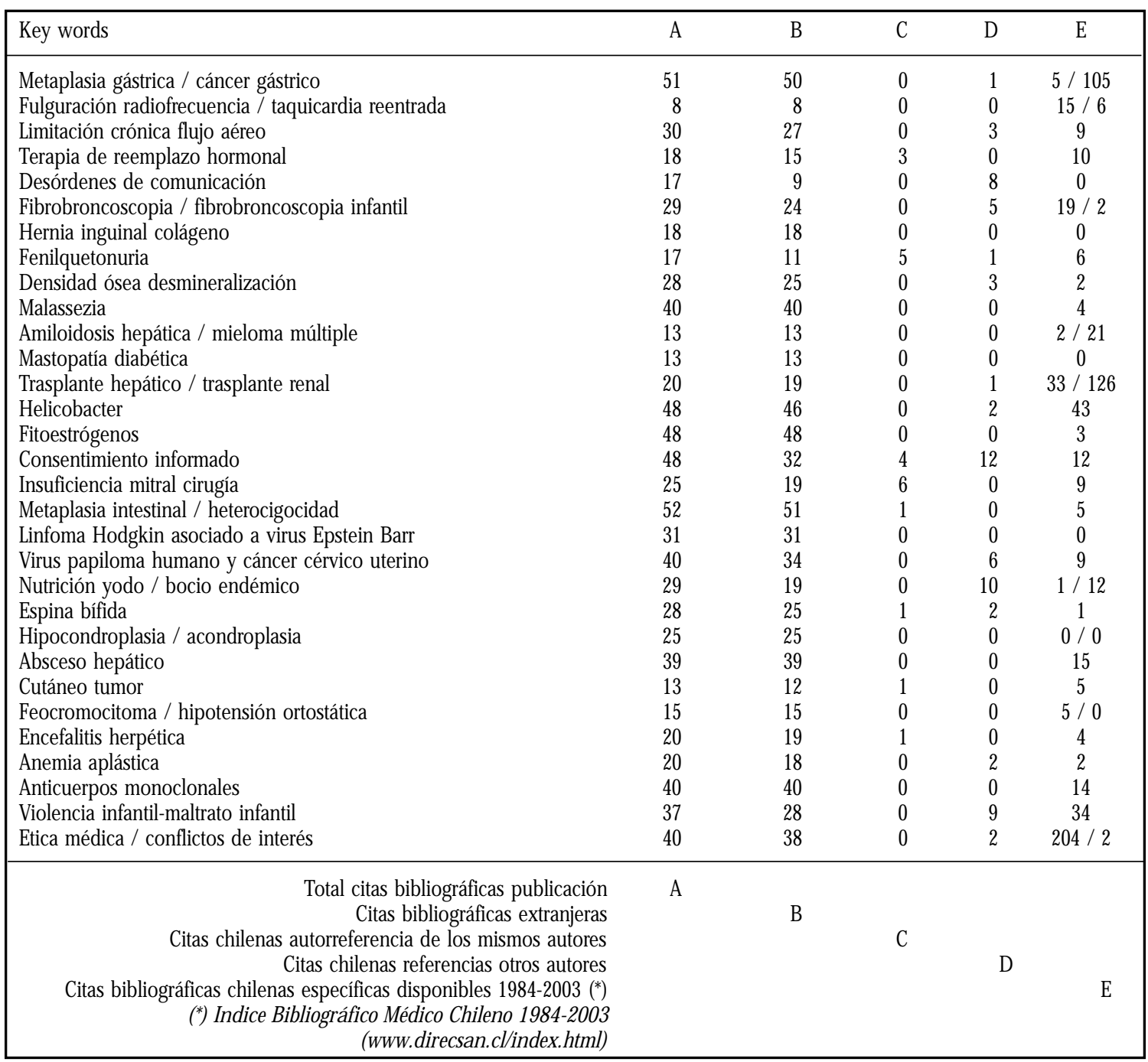

